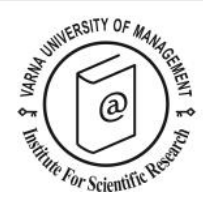

\title{
Extending collaborative consumption concept to yacht charter services: The case of Blue Voyage
}

\author{
Neslihan Paker ${ }^{1 *}$ and Osman Gök ${ }^{2}$
}

${ }^{1}$ Izmir Kavram Vocational School of Higher Education, Department of Logistics, Izmir, Turkey. E-mail: pakerneslihan@gmail.com

${ }^{2}$ Yasar University, Department of Business Administration, Izmir, Turkey. E-mail: osman.gok@yasar.edu.tr

* Corresponding author

\begin{abstract}
Collaborative consumption (CC) is a form of sharing in which participants jointly conduct services thereby creating a variety of benefits ranging from economic to social. CC has been widely studied in the hospitality industry, but yacht charter services have not been examined within this concept. Customer-to-customer interaction, which is an important element of the value-creation process, has not been discussed together with CC. The purpose of the study is to extend the concept of CC regarding yacht charter services as a new field of study. Blue Voyage, used as the research context, corresponds to a Turkish yacht charter concept that describes the circumstances in which voyagers live together in a limited space and share all services provided for a week. Twenty-four in-depth interviews were conducted with demographically diverse experienced or potential customers along with auto-ethnographic research. The data were analyzed via content analysis as a result of which three categories emerged as core benefits, perceived risks, and expected service elements. According to the study findings, the intense customer-to-customer interactions due to CC are inevitable in the yacht, which satisfies the social needs of the voyagers while also triggering risks related with sharing. The results offer important implications for such interaction-collaborativebased services.
\end{abstract}

Keywords: blue voyage; collaborative consumption; customer-to-customer interaction; services marketing; marine tourism

Citation: Paker, N. and Gök, O. (2021). Extending collaborative consumption concept to yacht charter services: the case of Blue Voyage. European Journal of Tourism Research 28, 2808. 


\section{Introduction}

In the last years, consumer behavior has moved toward collaborative consumption. The reasons behind this phenomenon are that consumers have reconsidered the value of money because of economic recession and become more willing to take responsibility in environmental sustainability. This movement is expected to continue, and some suggest that it will be one of the most effective game changers for the world (Walsh, 2011). Inevitability, many industries have been affected by this trend, especially transportation (e.g., Zipcar, Uber) and accommodations (e.g., Airbnb) services. However, marine tourism services have not been examined in the context of collaborative consumption in the literature.

Marine tourism carries utmost importance as a type of tourism in a national economy (Miller and Auyong, 1991; Orams, 1996; Hall, 2001; Chen, Wu and Chen, 2010). Based on the European Commission Report (2014), coastal and maritime tourism in Europe generates a total of $€ 183$ billion in gross value added which represents over one third of the maritime economy. The yacht charter is an important part of marine tourism. The Turkish Chamber of Shipping (TCS, 2019) estimates that Turkey's marine tourism revenue accounts for about $20 \%$ of total tourism revenues, and that premium products and services offered by yacht tourism comprise a high portion of that income. Moreover, it is estimated that the interest in yacht rental services will increase due to the Coronavirus crisis, as it provides a holiday away from the mass tourism (Forbes, 2020).

Spain, Italy, Greece, France, Croatia and Turkey are the most prominent destinations in the Mediterranean Basin with regard to the global yachting industry. The primary advantages of these countries are that they have many bays or islands, nice weather throughout the year, attractive sea characteristics in addition to cultural and historical sites. Turkey has a long zigzag-shaped coastline with several sheltered coves setting it aside from other destinations. Blue Voyage (BV) that dates back more than 70 years, is a crewed-type yacht charter and a special national marine tourism concept in Turkey. Generally, it is arranged as a one-week yacht tour, and transportation, cooking, and housekeeping are provided by the crew. The voyagers rent a yacht together with friends or with other customers whom they have never met before. Thus, they jointly arrange the acquisition and distribution of the services which is defined as collaborative consumption in literature (Belk, 2014). Since the main purpose of BV is to let people experience the beauty of Turkish bays, the yacht used in BV is small enough to enter the bays. The customers share the dining table and sunbathing spots, and perhaps even share the shower with other customers. In appropriate weather, customers who want to experience the magnificent beauties of nature sleep side by side on the deck instead of in their cabins. This voyage experience reflects a striking example of collaborative consumption and creates intense face-to-face interactions among voyagers.

The study's priority is to extend the concept of collaborative consumption regarding yacht charter services as a new investigation area. Specifically, it aims to reveal: 1) the dynamics of yacht charter services in the context of collaborative consumption 2) how these dynamics change the service design. The study scrutinizes the salient aspects influencing yacht chartering services and reveals the underlying motivation factors leading customers to collaborative consumption. The present study also addresses customer-to-customer interaction (CCI) issues. Although some recent studies have focused on collaborative consumption, the topic has not been examined in conjunction with the CCI concept (Rihova, Buhalis, Moital and Gouthro, 2015). Hence, the research service settings encompass attributes based not only on physical structures (e.g., yacht) but also on human beings. Moreover, service-specific risks (e.g., sharing risks) due to intense interactions among customers are questioned in the study that 
can be used by yacht charter managers for designing their services. The blue voyage has been used as a research setting in relation with the study objectives due to its relevant service characteristics.

In the following sections, an overview of the theoretical background and the state of research on the sharing and collaborative consumption concepts, customer-to-customer interaction, and BV service are presented. Thereafter, the findings of 24 in-depth interviews conducted with customers and autoethnographic research are provided. The results, suggestions, and limitations are discussed at the end of the study.

\section{Literature Review}

The Sharing Concept and Collaborative Consumption

The sharing concept is one of today's remarkable phenomena in various marketplaces (Cheng, 2016), and it takes on a wide range of forms, extending from sharing interest via online resources to renting idle capacities of goods or services temporarily. However, sharing has a long history (Belk, 2014; Frenken and Schor, 2017), and the trend, specifically, the sharing economy, gained economic value and popularity via Airbnb in 2007 (Guttentag, 2015). Thereafter, new companies such as Car2go, Zipcar, Uber, and Nice Ride emerged on the playing field. Furthermore, certain well-known companies positioned a few products targeting this market, such as AT\&T's 'Smart Limits for Wireless' (Lamberton and Rose, 2012). This movement is expected to grow up to $\$ 335$ billion by 2025 (PwC, 2015). Parallel to the increasing interest in the sharing economy in the market, academicians also focused on the concept of sharing and the 'sharing economy,' 'peer-to-peer sharing,' 'collaborative economy,' 'collaborative consumption,' and 'access-based consumption' are mentioned together in this context. However, the definitional differences between these concepts are not clear-cut and the area is still open to development.

Collaborative consumption is a form of sharing (Cheng, 2016), and it can be used in the same sense as the sharing economy (Perren and Grauerholz, 2015; Amaro, Andreu, and Huang, 2018). Scholars have also claimed that they are completely different concepts since sharing is not a market-mediated phenomenon; it occurs within socially connected groups (Benoit, Baker, Bolton, Gruber and Kandampullye, 2017). With a wide perspective, Felson and Spaeth (1978, p. 614) define collaborative consumption as when "one or more persons consume economic goods and services in process of engaging in joint activities with one or more others". However, Belk's (2014) proposition is a little different. He states that "collaborative consumption is people coordinating the acquisition and distribution of a resource for a fee or other compensation" (p. 1597). Thus, if no compensation is given for goods or services, it must be excluded from the concept. Ertz, Durif and Arcand (2019) have recently put forth that collaborative consumption can be defined as "the set of resource circulation schemes that enable consumers to both receive and provide, temporarily or permanently, valuable resources or services through direct interaction with other consumers or through an intermediary" (p.32). According to Felson and Spaeth (1978), direct contact collaboration requires consumption together with others at the same time and at the same place. Thus, a temporary community emerges, and interaction becomes a key facilitator of direct collaborative consumption. On the other hand, Huber (2017) defined direct interaction not as a form of collaborative consumption but as a necessity. He offers collaborative consumption essentials as "the engagement of at least two individuals who get involved in direct interaction and make use of the same units of goods and services" (p.53).

The sharing concept and collaborative consumption have been examined in the literature via various dimensions. For example, the motivations which make these concepts so popular are explained with mostly utilitarian-based approaches such as providing flexibility in terms of timing, utility, price, 
maintenance service, and storage options to customers (Barthi and Eckhardt, 2012; Fang, 2015). Some studies have also emphasized that the concepts allow customers to behave in a more environmentally friendly manner thanks to resource efficiency (Leismann, Schmitt, Rohn and Baedeker, 2013; Benoit et al., 2017). Furthermore, the gains in hedonic value with cheaper prices due to creating chances to experience new or luxury products/services have been put forward as a benefit (Barthi and Eckhardt, 2012). Beyond these rational reasons, some research on the concepts has shown that social interaction such as meeting new people, making friends, and community belonging are also main motivations of the concept (Möhlmann, 2015; Tussyadiah, 2015; Karlsson and Dolnicar, 2016; Mahadevan, 2018; Tussyadiah and Pesonen, 2018). Piscicelli, Cooper, and Fisher (2015) claim that collaborative consumption can enable opportunities to create a more bonded community. Fraanje and Spaargaren's (2019:506) findings indicate that customers of Peerby seek "a type of collaborative consumption that lets them share possessions with others, creating a sense of neighbourliness". Hence, sharing is a way to live an authentic experience in tourism (Cheng, 2016; Lin, Zhang, Gursoy and Fu, 2019), which provides a social exchange as well as economic incentive in the service environment. Interestingly, social interaction may be a barrier for not participating in such services. It was concluded in the study by Hazee et al. (2020), that some actors abstained from such services on grounds that they do not like social interaction.

Despite all the appeal, there are also worrisome aspects associated with the concept. The literature states that especially if there is a spatial closeness between people (strangers) in the service environment, there is a high degree of security risk for customers (Yang, Song, Chen and Xia, 2017). Cheng and Jin's (2019) study point out that Airbnb guests pay significant attention to privacy and safety as fundamental guarantees provided by hotels. Moon, Miao, Hanks and Line's (2019) study on Airbnb services indicates that both the hosts and guests perceive a high risk of uncertainty because they do not know each other. Interestingly, in the study of Albinsson, Perera, Nafees and Burman (2019), taking a risk by participating in collaborative consumption is a motivation per se. Furthermore, trust has crucial importance for the concept (Möhlmann, 2015; Cheng, 2016; Ert, Fleischer, and Magen, 2016; Karlsson, Kemperman, and Dolnicar, 2017; Mahadevan, 2018; Phua, 2018). Tussyadiah's (2015) study on peer-topeer accommodation rental services shows that the most effective deterrents to collaborative consumption are lack of trust related to safety and privacy, as well as toward host(s). Moreover, scholars have pointed out the scarcity of regulatory issues related to the concept (Guttentag, 2015; Dolnicar, 2019). Hartl, Hoffman and Kirchler's (2016) study on governance support for the regulation system has meant that more people will join in collaborative consumption if the goods and services they want to access are controlled.

\section{The Interaction Concept and Customer-to-Customer Interaction}

Collaborative consumption corresponds to the realm of interaction, which is one of the main drivers of the well-known lens of service dominant logic (SDL). Indeed, the pioneering authors of SDL emphasized the central role of interaction in the value concept of services (Vargo \& Lusch, 2004; Grönroos, 2008). For example, Grönroos (2006, p. 323) states that services create value through "processes that consist of a set of activities which take place in interactions between a customer and people resources." Furthermore, Ramaswamy (2011, p. 195) argues that "value is a function of human experiences...and experiences come from interactions." In this context, value co-creation has also been mentioned as a form of interaction, an output of a collaboration (Lin, Chen, and Filieri, 2017). Rihova et al., (2015) emphasize that, depending on the nature of the tourism context, co-creation of value can be reproduced by sharing experience and practicing social interactions with others in the society. Hence, the interaction has been defined as an inseparable part of the services, and the actors contributing to the value creation process through interaction are essential elements. Among them, the impact of other 
customers, perhaps the most complex and most difficult manageable element of the service encounter, has gained less academic attention than other service elements in the literature (Miao, Mattila, and Mount, 2011; Rihova et al., 2015; Wei, Lu, Miao, Cai and Wang, 2017). Thus, Customer-to-customer interaction (CCI) literature has remained immature despite the important effect on perceived value, service quality, customer satisfaction, customer retention, and the value creation process (Pranter and Martin, 1991; Guenzi and Pelloni, 2004; Gruen, Osmonbekov, and Czaplewski, 2007; Wu and Liang, 2009; Yoo, Arnold, and Frankwick, 2012; Lin et al., 2019; Nguyen, Ferraro and Sand, 2020).

Considering the satisfaction/dissatisfaction effect, scholars have examined CCI based on two approaches that may create friendship opportunities or unbearable situations due to the inappropriate behavior of other customers. Yoo, Arnold, and Frankwick (2012) suggest that friendly approach of other customers increases the perceived service quality and satisfaction in hospital services. Altinay, Song, Madanoglu and Wang's study (2019) revealed that local coffee shops provide an opportunity for social exchange that affects satisfaction and well-being thus helping to mitigate the social isolation of elderly people. Wu and Liang (2009) point out that interaction enhances experiential value and satisfaction in luxury restaurants and that it also involves some inappropriate behaviors. Similarly, Huang and Hsu (2010) put forward two opposing aspects of CCI (e.g., hostile or friendly, competitive or cooperative) for cruise customers, and the study reveals that the quality of CCI has a positive effect on cruise experience and satisfaction.

Scholars have discussed the factors that affect CCI as well. According to Martin and Pranter (1989, p. 712), "consumers may intuitively gravitate toward those service environments with which they are most compatible", and this tendency depends on homogeneity among customers. In this context, the similarity is mentioned as a salient factor of CCI. Indeed, similarity among customers has enabled puzzling out social agreements more efficiently, and with similarity trust is established more easily (Lamberton and Rose, 2012; Lin et al., 2019). Moreover, individuals are more comfortable with others who are similar (Brocato, Vooerhees and Baker, 2012; Hyun and Han, 2015). Nguyen, Ferraro and Sand (2020) tested whether congruency in customer characteristics (e.g., appearance, behavior, and emotion) increases focal customer outcomes (e.g., satisfaction, hedonic value, purchase intention) for the food service industry. The findings demonstrate that congruence in customer characteristics can positively affect the outcomes in the high involvement setting, but not in low involvement settings.

Papathanassis (2012) posits that excluding situational factors, considering just the compatibility/homogeneity characteristics of customers, is not sufficient to depict customer satisfaction. The intensity, amount of time spent together, and physical proximity can have a positive effect on building the group formation that fosters customer interaction in a positive way. However, this can also create difficulties while sharing limited resources such as seating, food, and sun-bathing spots. In addition, $\mathrm{Wu}(2007)$ claims that the effect of homogeneity on satisfaction is more important on long trips than on shorter ones. Besides, Nicholls (2020) points out that CCI types (e.g., queuing discipline, disrespectful attitude) can vary depending on the industry (e.g., on a train, in a library), so practitioners should develop service-specific settings.

\section{Theories Related to CCI}

Despite its relevance, $\mathrm{CCI}$ is a difficult topic to be approached by scholars in the literature (Miao, Mattila and Mount, 2011). Since many psychological and social factors affect consumer behavior (Heitmann, 2011), it is difficult to explain the CCI behavior with any single theory alone. We suggest two propositions taking into consideration two main questions: (1) "Why do customers need interaction with others in the service environment" and (2) "why do people have to behave appropriately?" The first question 
suggests that CCI refers to a person's social need. In tourism studies, two theories that explain the motivations behind a customer's orientation to touristic activities can be used to support this relationship. According to travel career ladder theory (Pierce and Lee, 2005), the social relationship is one of travelers' motivation. Furthermore, leisure motivation theory (Beard and Ragheb, 1983), defines social need as a motivation as well. These theories are based on Maslow's needs hierarchy theory, which is one of the most influential theories in Social Sciences (Simkova and Holzner, 2014). Second, we posit that CCI is also a self-esteem enhancer. Leary (2005, p. 75) claims that "people seek to increase their relational value and social acceptance, using self-esteem as a gauge of their effectiveness" in sociometer theory. The author also proposes that social rejection has a greater effect on self-esteem than acceptance, and people think that social rejection is a result of their behaviors. Hence, various behavior rules dictate belonging to a community; these rules are called scripts (Miao, Mattila and Mount, 2011). Scripts are social forces that are explained with social impact theory (Latane, 1981). Moreover, social identity theory, proposed by Tajfel and Turner (Leary, 2005), which is related to being a group member, also increases or decreases self-esteem and can be considered in this context. Therefore, customers must obey rules if they want to be members of a group or at least do not want to be excluded from the society, which results in a decrease in self-esteem and thus well-being.

\section{Methodology}

BV as a Collaborative Consumption Example: The Turkish Case

Turkey is one of the most popular countries for yachting in the Mediterranean Basin. It has a long yachting season, running from April until October (Sevinç and Güzel, 2017), and the sea water temperature is especially suitable for yachting. Furthermore, since the "Aegean Coast of Turkey has a zigzag-shaped, there are several sheltered bays and coves” (TCS, 2016, p. 6). According to given statistics, 239 bays are available between the "Gulf of Edremit and Antalya-Phaselis, and the most preferred yacht chartering route starts from Kuşadası down to Antalya whose length is 350 sea miles” (TCS, 2016, p. 93). In addition, Turkey has many hot spots for yachting destinations, such as the Lycian Way, Kleopatra Public Bath Bay, Ancient Loryma Mud Bath, and Caretta Caretta Beach. These characteristics differentiate Turkey from other countries in the yacht charter market. Turkey is home to 1,811 licensed yachts (excluding daily tour yachts) having 18,163 accommodations capacity (TCKTB, 2018).

BV has held an important share in local and foreign tourism, and it is estimated that 100,0oo foreign and local tourists experience BV every year (Albachten, 2012). It offers a crewed type of yacht charter, and generally the duration of the voyage is one week. The cabins have double beds, and almost all have had their own private shower and toilet. The most preferred yacht size is big enough for eight cabins, which means approximately 20 people, including crew, share the yacht and services. The yacht can be arranged as both exclusive and cabin charter, which can be defined as collaborative consumption. An exclusive yacht charter means that the customer rents all the cabins in a yacht, and the customers bring their family and close friends to share the service. In the cabin charter, the customer rents just one or several cabins instead of all of them. The other passengers are customers who have purchased the voyage from the yacht company. Yacht rental is a premium service, and is not affordable for people who do not have a significant income. All expenses for the received services are divided equally between the voyagers. Therefore, it is transformed into an economically accessible service by adopting a sharing economy lens. The most challenging aspect is that customers must share limited space with people they have not met before. In some cases, customers who have shared previous voyages can decide to rent a yacht together for their next voyage. In some cases, customers might come from different nations, which creates cultural exchange opportunities. The essential services given in BV include cleaning, cooking, and transportation. In addition, some activities such as cycling, and trekking are also offered for the 
customers' enjoyment. These activities offer opportunities for customers to develop relationships with each other.

\section{Data Collection and Sample Characteristics}

The interpretivist paradigm is preferred and consists of two methods to conceptualize this untouched value-laden phenomenon appropriately which are interviews via customers and auto-ethnographic research. During the interview part of the research, the concept was discussed with potential and existing customers during in-depth interviews. Criterion sampling from among purposive sampling methods was used to select interviewees. Twenty-four semi-structured in-depth interviews were conducted. The questions were asked to evaluate the BV experience based on the following questions: "What is your desired outcome/benefit from a BV offer?" (Alam, 2006), "What would your dream BV holiday be like?" (Konu, 2015), "Do you think that BV has some risks? What type of risks do you foresee?", "What are your thoughts on cabin chartering?". Some of the interview questions were taken from the field of New Service Development, which is based on the Service Dominant Logic paradigm. Interviews were conducted by the first author between March 2017 and April 2018, and 98 computerwritten pages and 19 hours of sound were recorded. The average duration of the interviews was 48 minutes. Afterward, to increase the validity of the research results, the first author also conducted autoethnographic research. In September 2017, the first author participated a cabin charter type of BV for four days to get firsthand experience. Considering the difficulty of being both an observer and a participant at the same time, she decided to become a participant only and focused on her own experience in the research. However, as other people on the yacht were part of her experience, she had the chance to observe them as well. The researcher explained that she was studying the BV concept and would make observations during the journey. The profile of the sample and the characteristics of each respondent are seen in Table 1 , and Table 2 , respectively.

Table 1. Summary of Sample Characteristics

$\begin{array}{ll}\text { Number of } & \text { Number of } \\ \text { Respondents }(\mathrm{N}=24) & \text { Respondents }(\mathrm{N}=24)\end{array}$

\begin{tabular}{llll}
\hline Age & & Income Level & \\
$20-29$ & 2 & Mid-Level & 9 \\
$30-39$ & 6 & Upper Mid-Level & 12 \\
$40-49$ & 7 & High & 2 \\
$50-59$ & 4 & Very High & 1 \\
$60-69$ & 4 & Marital Status & \\
$70-$ over & 1 & Married/Living & 16 \\
& & Together & \\
Gender & & Single & 8 \\
Male & 7 & Blue Voyage & \\
Female & 17 & Experience & \\
& & None & 11 \\
Education & & 1 time & 3 \\
High School & 2 & $2-3$ times & 2 \\
Undergraduate & 14 & 4 or more times & 8 \\
Post Graduate & 8 & & \\
\hline
\end{tabular}


Table 2. Characteristics of The Respondents

\begin{tabular}{|c|c|c|c|c|c|c|}
\hline $\begin{array}{l}\text { Respon- } \\
\text { dent }\end{array}$ & Occupation & Education Level & Age & Income Level & Marital Status & $\begin{array}{l}\text { Yacht } \\
\text { Chartering } \\
\text { (BV) } \\
\text { Experience }\end{array}$ \\
\hline $\mathrm{R} 1$ & $\begin{array}{l}\text { Illusionist\& } \\
\text { Engineer }\end{array}$ & Master Degree & 48 & Upper midlevel & $\begin{array}{l}\text { Married/parent } \\
\text { of a toddler }\end{array}$ & - \\
\hline $\mathrm{R}_{2}$ & $\begin{array}{l}\text { Occupational } \\
\text { Safety } \\
\text { Specialist }\end{array}$ & Undergraduate & 42 & High & $\begin{array}{l}\text { Married/parent } \\
\text { of a toddler }\end{array}$ & - \\
\hline $\mathrm{R}_{3}$ & $\begin{array}{l}\text { Retired } \\
\text { banker }\end{array}$ & High School & 57 & Midlevel & Married & 7 times \\
\hline $\mathrm{R}_{4}$ & $\begin{array}{l}\text { Retired } \\
\text { banker }\end{array}$ & High School & 63 & Midlevel & Married & 7 times \\
\hline $\mathrm{R}_{5}$ & $\begin{array}{l}\text { Zumba } \\
\text { trainer \& } \\
\text { Engineer }\end{array}$ & Undergraduate & 27 & Midlevel & Single & - \\
\hline R6 & $\begin{array}{l}\text { Quality } \\
\text { Assurance } \\
\text { Specialist }\end{array}$ & Undergraduate & 47 & Upper midlevel & $\begin{array}{l}\text { Married/parent } \\
\text { of a toddler }\end{array}$ & 1 time \\
\hline $\mathrm{R}_{7}$ & $\begin{array}{l}\text { Material } \\
\text { Safety } \\
\text { Specialist }\end{array}$ & Master Degree & 39 & Upper midlevel & Single & - \\
\hline $\mathrm{R} 8$ & Academician & $\mathrm{PhD}$ & 35 & Upper midlevel & Single & - \\
\hline R9 & Stockbroker & Undergraduate & 49 & Upper midlevel & $\begin{array}{l}\text { Married/parent } \\
\text { of a toddler }\end{array}$ & 6 times \\
\hline Rio & Housewife & Undergraduate & 45 & Very high level & $\begin{array}{l}\text { Married/parent } \\
\text { of a toddler }\end{array}$ & $>8$ times \\
\hline R11 & Architect & Undergraduate & 70 & High & Single & - \\
\hline $\mathrm{R} 12$ & PhD Student & Master Degree & 28 & Midlevel & Single & - \\
\hline $\mathrm{R}_{13}$ & Journalist & Undergraduate & 34 & Midlevel & $\begin{array}{l}\text { Married/parent } \\
\text { of a toddler }\end{array}$ & 1 times \\
\hline R14 & $\begin{array}{l}\text { Marine } \\
\text { Captain }\end{array}$ & Undergraduate & 45 & Upper midlevel & $\begin{array}{l}\text { Married/parent } \\
\text { of a toddler }\end{array}$ & - \\
\hline $\mathrm{R} 15$ & Engineer & Undergraduate & 32 & Upper midlevel & Single & - \\
\hline R16 & Academician & Master Degree & 35 & Upper midlevel & $\begin{array}{l}\text { Married/parent } \\
\text { of a toddler }\end{array}$ & - \\
\hline $\mathrm{R} 17$ & Auditor & Undergraduate & 50 & Midlevel & Married & $>8$ times \\
\hline $\mathrm{R} 18$ & $\begin{array}{l}\text { Financial } \\
\text { Advisor }\end{array}$ & Undergraduate & 66 & Upper Midlevel & Married & $>8$ times \\
\hline Ri9 & $\begin{array}{l}\text { Retired } \\
\text { teacher }\end{array}$ & Undergraduate & 51 & Midlevel & Single & 1 time \\
\hline $\mathrm{R}_{20}$ & Lawyer & Undergraduate & 66 & Upper Midlevel & Married & $>8$ times \\
\hline $\mathrm{R}_{21}$ & $\begin{array}{l}\text { Retired } \\
\text { Marketing } \\
\text { Manager }\end{array}$ & Master Degree & 68 & Upper Midlevel & Married & $>8$ times \\
\hline $\mathrm{R}_{22}$ & $\begin{array}{l}\text { Real Estate } \\
\text { Agent }\end{array}$ & Undergraduate & 41 & Midlevel & Single & 2 times \\
\hline $\mathrm{R}_{23}$ & $\begin{array}{l}\text { Customs } \\
\text { Chief } \\
\text { Inspector }\end{array}$ & Master Degree & 37 & Upper Midlevel & Married & 2 times \\
\hline R24 & Academician & Master Degree & 50 & Midlevel & Married & - \\
\hline
\end{tabular}




\section{Data Analysis}

All transcripts were analyzed by content analysis via Atlas.ti. A procedure was prepared and followed in this study in response to the call by Camprubi and Coromina (2016) criticizing the shortcomings of tourism studies in terms of content analysis. The schema obtained during the open-coding stage was evaluated many times by the first author in order to increase intra-coder reliability (Krippendorff, 2013). The categories were reevaluated by a senior marketing academician, who was also the second author and coder of the research, in an effort to increase the credibility of the study in the axial coding stage. Conventional content analysis approach was preferred since the aim of the study was to develop the yacht charter service concept (Hsieh and Shannon, 2005). The first author provided simple definitions for almost all categories in addition to defining the rules for coding. Nominal coding in the form of agree or disagree was determined for coding. The coder training stage focused on the rules of analysis since the second coder had sufficient knowledge to evaluate the topic under investigation.

The consistency between the coders was slightly above $80 \%$ in the pre-test stage. All transcripts including the auto-ethnographic research were coded after some revisions and 650 content units were obtained by the first coder. The formula suggested by Lacy and Riffe (1997) was used to calculate the number of content units needed for an inter-reliability test. The units were chosen based on random numbers generated in Excel. The second author evaluated the units using the coding procedure. Based on the test, inter-coder consistency was determined approximately as $89 \%$ for Cohen's kappa coefficient via SPSS. The study results were accepted as reliable since the kappa coefficient was above the accepted level of agreement set forth as $80 \%$ in academic studies. The coders discussed the areas of disagreement after which a consensus was provided for all units of analysis. Figure 1 shows the analysis procedure, and Table 3 presents the final coding table. 


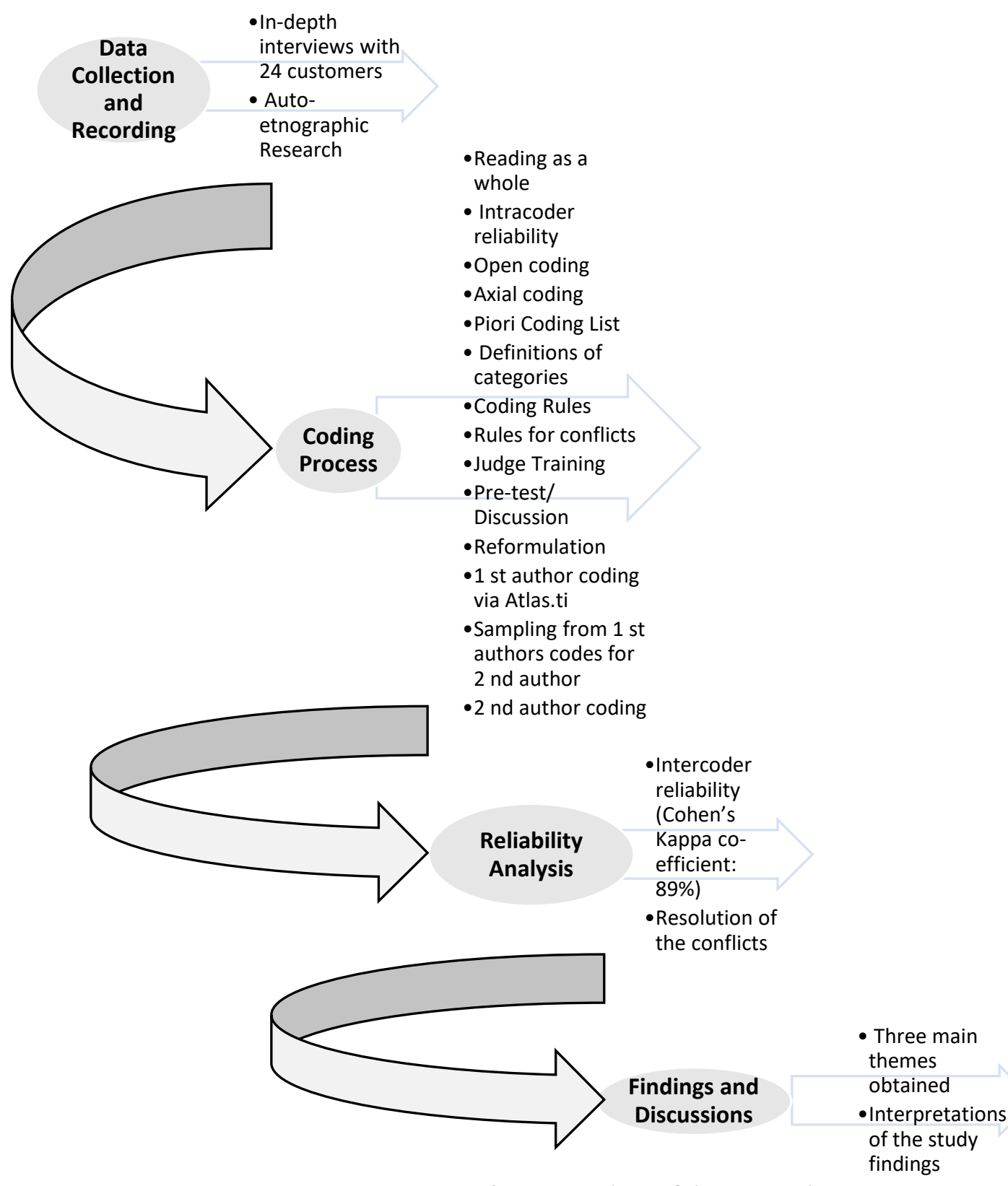

Figure 1. Analysis Procedure of the Research 
Table 3. The Final Coding Table.

\begin{tabular}{ll}
\hline Themes & \\
\hline 1- Core Benefit & 3. Perceived Risks \\
1.1. Social & 3.1. Sharing \\
1.2. Economic & 3.2. Psychological \\
1.3. Nature Based Motivations & 3.3.Other risks \\
2- Expected Yacht Charter Service Concept & \\
2.1. Yacht & \\
2.2. Crew & \\
2.3. Other Customers & \\
2.4. Services & \\
2.5. Activities & \\
\hline
\end{tabular}

\section{Results}

The comments received on BV experience, specifically collaborative consumption, are presented below:

\section{Core Benefit}

Social

$\mathrm{BV}$ is a social activity held in nature that enables the experiencing of living as a community for a week. The customers who prefer the voyage desire to meet their social needs through spending time with family and friends, meeting new people, and developing friendships during the voyage. " $B V$ is not a journey you go alone" [R4]. "While the evening sun goes down, playing cards with people that sit around the same table is a pleasure" [R6]. "I like the idea of being with people from different cultures" [The First Author]. I prefer that; let people get very close and get new acquaintances" [R17].

\section{Economic}

BV is a kind of sharing economy service that makes it affordable despite being a premium product. The expenditures are shared by a group of people who knows each other or not. The cabin charter type is an option when customers have not enough fellow travelers or money "It's more reasonable to rent a cabin than rent a yacht. You can't gather that big amount of friends" [R5]

\section{Nature Based Motivations}

$\mathrm{BV}$ is a nature-based service experience with primary features of sensing the natural beauty of the sea and shoreline within the virgin nature, and feeling peace and relaxation in such an environment. "I come to peace, listen to the nature. Every day I sleep and eat in a different bay, there is no luxury" [R9]

\section{Expected Yacht Charter Service Concept}

Attributes of the concept are defined as yacht, crew, other customers, services, and activities.

\section{Yacht}

Gulet-type yachts are the most preferred yachts which are handmade, wooden, and specific to Turkey. They provide not only safe transportation but also a comfortable holiday experience. In particular, their communal living spaces such as dining tables and sun-bathing lounges are large enough to provide privacy. "I know the yacht will not be a comfortable place, but it should be wide enough. People on the deck shouldn't go jumping over each other" [R1]. 
Crew

The human element has crucial value. The crew is expected to be clean, reliable, respectful, willing to serve, and competent at their job. It has more significance than the yacht and the tour can be completed in a pleasant way thanks to the mastery of the staff even if the yacht has minor shortcomings. " $B V d o e s n ' t$ end well if the crew can't fulfill the necessary attention" [R1o]. Some customers also expect the crew to take the initiative to establish friendship among customers.

\section{Other Customers}

Even if the tranquility sought in BV is provided through nature, it should never be disturbed by other people. Respondents emphasize similarity and harmony among customers as desired attributes. "When you go BV, your husband and you have to be in harmony with the others. Because there's nothing there except them! If you're hesitant, you shouldn't go to BV with them" [R14].

\section{Services and Activities}

Safe transportation, cooking, and cleaning are the essential services that customers expect to be provided at high-quality. "Everything you get on time, get clean, enough. No special service required" [R19]. In addition, the customers stated that activities such as historical and gourmet tours, sailing lessons, trekking, and karaoke or dance parties can be scheduled by the organization.

\section{Perceived Risks}

\section{Sharing}

Intense CCI triggers sharing risks. Results suggest major perceived risks such as the possibility of some customers disobeying the rules as well as acting in a disrespectful manner to privacy. Majority of the interviewees expressed serious concerns with regard to the sharing of risks that arise due to interaction with others. "Before we went to $B V$, we came together with the people to test if we would be together, we ate, and drank 4-5 times! To get to know each other" [R23]. Some customers worry that the other customers will make the BV experience unbearable, even if they know each other. "Even with your friend you know best, different personalities can appear on the boat" [R18] The crew also shares a small physical environment together with the customers. Poor-quality interaction between the crew and customers may also lead to problems on the yacht. "Passengers are so elite but I think of how to protect the distance with the crew in such a small space" [The First Author].

\section{Psychological}

The interviewees stated that such a unique service environment may result in some anxieties related with boredom or feeling overwhelmed due to having no alternative place to escape. "Five days in the same place... I can get bored, I don't know" [R12]. "My other friends don't prefer BV because they think they won't live in such a small area" [R21]

\section{Other risks (Physical, Performance)}

Natural disasters and health emergencies were also mentioned in this category. Families with toddlers are also concerned about injuries on the yacht. The risks related to expected outcomes such as service quality and weather conditions are also mentioned under this category.

The BV concept design is depicted in Figure 2 based on the discourses. 


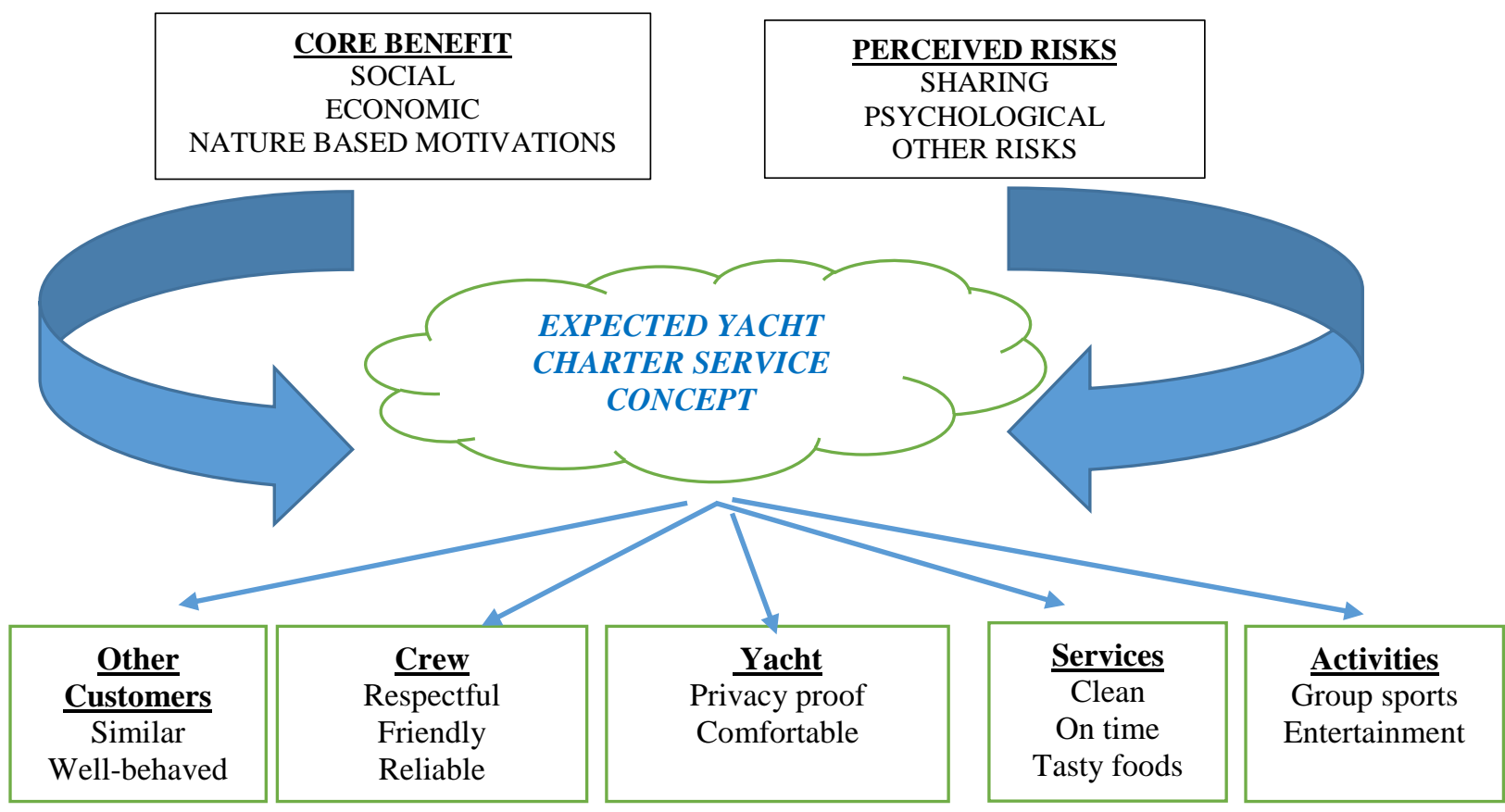

Figure 2. Yacht Charter Service Concept Design

\section{Discussion and Conclusion}

The present study was the first attempt to frame the collaborative consumption concept for yacht charter services. Three main themes emerge as; core benefits, perceived risks and expected service elements for yacht charter services considering the collaborative consumption context. In addition, the results reveal major satisfaction determinants of BV as customer similarity, sufficient space for privacy, reliable and respectful crew.

In the light of the findings of the study, the most salient point of the charter concept was observed as the fact that customers experience intense interaction not only with nature but also with other people on the yacht. The human interaction is a result of collaborative consumption, whether based on preference or necessity. Therefore, the element of "other customers" emerged naturally as a result of the study in addition to the nature-based characteristics of the yacht charter concept. The yacht charter customers share the costs while also engaging in social contact with the other voyagers, family, friends and also the yacht personnel. Hence, yacht charter customers perceive social benefits in this collaborative consumption environment, besides satisfying economic and nature based motivations. In particular, two dimensions have been mentioned frequently for "other customers". The first is that, other customers are expected to be good at sharing rights, respecting privacy, and living in harmony because they share the same environment due to collaborative consumption. The second aspect of "other customers" relates to developing friendship, which is one of the core benefits of the concept. Customers want the other customers to be similar to them. Hence, this finding is in accordance with the findings of previous scientific studies mentioned in the section of the study presenting the literature review on CCI interaction.

This social dimension can also be extended to encompass the crew. The results show that the most frequently stated expectations regarding the crew are concerned with their behavior and attitude and 
include being respectful of the customers' privacy needs. In addition, some customers mentioned that the crew should organize entertaining activities or even act as a friend. Undoubtedly, the crew has a crucial effect on the provided service. Tajeddini (2011) emphasizes that employees have sometimes been regarded as the service itself. However, this kind of expectation can be explained by the fact that the crew and customers interact intensively and establish close relationships for a long period of time on the yacht.

The expected characteristics of the yacht also differ due to collaborative consumption. Customers indicated cabin comfort as the most important factor, and they also wanted to have enough space in shared areas such as the deck and dining table. This can be interpreted based on the fact that collaborative consumption also involves risks of privacy violation which can be handled better by way of the aforementioned attributes.

The intense CCI triggers sharing risks. Results suggest that major perceived risks involve the possibility that some customers will disobey the rules and display behaviors disrespectful to privacy. Generally, customers stated that this is not such a deterrent as to stop them from buying BV. However, they have some anxieties. Since the concept requires sharing all services provided in a limited physical area, appropriate behavior of other customers and crew gains more importance for customers. Some customers worried that the other customers might make the BV experience unbearable. Even if customers know the other travelers, they still might have problems. To the best of our knowledge, this kind of risk is not defined in the perceived risk literature. At first glance, one might think this risk is related to social and psychological risk. However, the existing definitions are different. For example, Fuchs and Reichel (2006, p. 84) and Reichel, Fuchs and Uriely (2007, p. 218) define social risk as "the fear that the purchase will not conform to the standards of the reference group" and psychological risk as "the fear that the product will not be compatible with the self-image of the consumer," respectively. Some authors have combined these two risk and considered them to be a psychosocial risk. However, again, they define it as embarrassment and loss of self-esteem (Mitchell and Greatorex, 1993). The likely problems that cause sharing risk are stated in some academic studies (Papathanassis, 2012; Martin, 2016); however, they have not been studied within the perceived risk concept.

Furthermore, such a unique service environment may result in some anxieties related with boredom or feeling overwhelmed due to having no alternative place to escape. This mentioned risk can be considered as psychological risk; however, it differs from the definition stated in the literature. Thus, a new sub-risk can emerge depending on the context.

\section{Theoretical Contributions}

Although collaborative consumption has been studied in the hospitality industry, the yacht charter services have not been examined within this concept. The yacht charter service creates an intense experience in the customers with voyagers they have never met before, while also providing them with no opportunity to give up on the service immediately if they are bored, uncomfortable or not satisfied with the service. This unique context differs from many other hospitality services and provides a remarkable area of investigation for collaborative consumption. Besides, Ertz, Durif and Arcand (2019) stated that certain forms of collaborative consumption evoke community-building and suggest that future studies should be carried out. The present study has witnessed the formation of a temporary community during the sharing of services, and thus contributes to this less handled aspect of the concept. 
Moreover, there is a limited number of studies in the relevant literature that examine both CCI and collaborative consumption concepts together despite the importance of value creation in services. Rihova et al. (2015) suggested that studies may be carried out in the future that examine the concept of shared consumption of tourists and guided tours for tourists who do not know each other, and Nicholls (2010) also emphasized that the CCI literature has mostly focused on short interactions among customers. This study has tried to fill these gaps in the services literature.

Furthermore, an undefined perceived risk factor emerged related to collaborative consumption depending on the behaviors of other customers and even the crew within this context. The psychological risk was enhanced with a different type of anxiety as well. This study also defines a procedure prior to the content analysis and applies numerous practices in response to the call for research by Camprubí and Coromina (2016).

\section{Managerial Implications}

The study also offers several strategic and managerial implications to design better services for such interaction collaborative based service settings. Yacht charter managers should primarily aim to reduce the perceived risks while increasing the social and economic benefits related to the service provided. Group discounts or bring-a-friend campaigns can be marketed (Martin, 2016), so the possibility of two benefits occurring at the same time can be increased. Customer segment-specific offers can be provided to different customer groups that come together in the service environment. Relevant physical arrangements that aim to prevent privacy violations in the yacht may also have a positive impact with regard to perceived risks. Preparing behavioral scripts to guide CCI interaction (Miao, Mattila, and Mount, 2011) and regulations (Wu, 2007) will also help in reducing inappropriate situations.

Moreoever, the yacht crew is especially important for handling cases of dissatisfaction and improving the quality of CCI interaction in such a service environment. As suggested by Pranter and Martin (1991), actualizing some roles such as acting as a teacher to educate customers on how they should act in the service environment or rewarding the most compatible customers will help to manage customer compatibility. In addition, the emotional needs of the customers should be taken into account as well as meeting the functional expectations since the service requires a relatively long period of time and physical proximity. Employees must perform sustained emotional labor towards customers in their relationships (Price, Arnould and Tierney, 1995). Hence, the relationship will transform into a commercial friendship, which will increase customer satisfaction and loyalty (Price and Arnould, 1999). Besides, courses can be arranged to train the crew and yacht company/agency representatives, particularly in hospitality, thus contributing to improving the quality of the yacht industry.

Furthermore, crew information can be provided on the web pages of companies and data on weather conditions can be shared with the customers in advance. As an example, in some sharing platforms such as Findacrew, the crew information is provided to the voyagers thus enabling them to choose the staff(s), they will be most satisfied with. Last but not least, although it has not been presented among research findings, environmental sustainability is one of the main benefits of collaborative consumption. Providing a briefing by the service managers on the yachters' effect on environmental sustainability will increase their awareness.

\section{Limitations of the Study and Suggestions for Future Research}

Customer variety with regard to nationality is a limitation of this study, since all respondents are Turkish. Hence, the approach of different cultures to the concept could not be investigated. In particular, we highly recommend cross-cultural studies for examining whether cultural background 
might have an impact on motivation, perceived risks, and expected service attributes related with collaborative consumption. For example, socialization may not be a significant motivation for customers who come from individualist cultures.

The study results indicate that customers have different expectations, so segmentation studies will help in developing the services presented and in reaching the targeted customers. For instance, personality traits (e.g., introverted vs extroverted, risk-seekers vs risk-avoiders), demographic variables (e.g., age, education level, and economic situation) of customers may require such services to be designed with different characteristics. Besides, social and economic benefits were seen among the core benefits of the study on collaborative consumption. Different service designs can also be developed for market segments, where one of these two benefits is noticeably outweighed. Segmentation analysis can also encompass the perceived risks mentioned in various studies. The study results indicate that there is heterogeneity in the market in terms of risk type and perceived level of risk. As an example, all customers perceived social risks, but experienced customers cared less about it or managed it better in case of negativity. Mitchell (1999) states that perceived risk analysis can yield new product ideas since the product can be developed based on reducing the perceived risks of customers. Moreover, future research may adopt a quantitative approach, and provide further empirical verification of the results.

\section{References}

Alam, I. and Perry, C. (2002). A customer-oriented new service development process. Journal of Services Marketing, 16(6), 515-534. doi: 10.1080/13683500.2018.1448368.

Alam, I. (2006). Removing the fuzziness from the fuzzy front-end of service innovations through customer interactions. Industrial Marketing Management, 35, 468 - 480.

Albinsson, P.A., Perera, B.Y., Nafees, L. and Burman, B. (2019). Collaborative Consumption Usage in the US and India: An Exploratory Study. Journal of Marketing Theory and Practice, 27(4), 390-412, DOI: 10.1080/10696679.2019.1644956.

Albachten, Ö.B. (2012). Mavi Yolculuk (Blue Voyage): A Journey of Self-Discovery during the Early Decades of the Turkish Republic (1945-1969). Studies in Travel Writing, 16(4), 427-439.

Alcover, A., Alemany, M., Jacob, M., Payeras, M., Garcia, A. and Ribes, L.M. (2011). The economic impact of yacht charter tourism on the Balearic economy. Tourism Economics, 17(3), 625-638. doi: 10.5367/te.2011.0045.

Altinay, L., Song, H., Madanoglu, M. and Wang, X.L. (2019). The influence of customer-to-customer interactions on elderly consumers' satisfaction and social well-being. International Journal of Hospitality Management, 78, 223-233.

Amaro, S., Andreu, L. and Huang, S. (2018). Millenials' intentions to book on Airbnb. Current Issues in Tourism, 22(18), 2284-2298. doi.org/10.1080/13683500.2018.1448368.

Aydin, S. and Özer, G. (2005). The analysis of antecedents of customer loyalty in the Turkish mobile telecommunication market. European Journal of Marketing, 39(7/8), 910-925. DOI $10.1108 / 03090560510601833$.

Barthi, F. and Eckhardt, G.M. (2012). Access-Based Consumption: The Case of Car Sharing. Journal of Consumer Research, 39, 881-898. DOI: 10.1086/ 666376.

Beard, J.G. and Ragheb, M.G. (1983). Measuring Leasure Motivation. Journal of Leusire Research, 15(3), 219-228. DOI: 10.1080/o0222216.1983.11969557.

Belk, R. (2014). You are what you can access: Sharing and collaborative consumption online. Journal of Business Research, 67, 1595-1600. http://dx.doi.org/10.1016/j.jbusres.2013.10.001.

Benoit, S., Baker, T.L., Bolton, R.N., Gruber, T. and Kandampullye, J. (2017). A triadic framework for collaborative consumption (CC): Motives, activities and resources and capabilities of actors. Journal of Business Research, 79, 219-227. http://dx.doi.org/10.1016/j.jbusres.2017.05.004. 
Bertella, G. (2013). Northern Lights Chase Tours. Experiences from Northern Norway. Journal of Northern Studies, 7(2), 95-116.

Brack, A.D. and Benkenstein, M. (2014). Responses to other similar customers in a service setting analyzing the moderating role of perceived performance risk. Journal of Services Marketing, 28(2), 138-146. https://doi.org/10.1108/JSM-05-2012-0089.

Brocato, E.D. Vooerhees, C. M. and Baker, J. (2012). Understanding the Influence of Cues from Other Customers in the Service Experience: A Scale Development and Validation. Journal of Retailing, 88(3), 384-398.

Camprubí, R. and Coromina, L. (2016). Content analysis in tourism research. Tourism Management Perspectives, 18, 134-140.

Chen, C.M., Lee, H.T., Chen, S.H. and Huang, T.H. (2011). Tourist Behavioural Intentions in Relation to Service Quality and Customer Satisfaction in Kinmen National Park, Taiwan. International Journal of Tourism Research, 13, 416-432.

Chen, S.C., Wu, M.C. and Chen, C.H. (2010). Employee's Personality Traits, Work Motivation and Innovative Behavior in Marine Tourism Industry. J. Service Science E Management, 3, 198-205. doi:10.4236/jssm.2010.32024.

Cheng, M. (2016). Sharing economy: A review and agenda for future research. International Journal of Hospitality Management, 57, 60-70.

Cheng, M. and Jin, X. (2019). What do Airbnb users care about? An analysis of online review comments. International Journal of Hospitality Management, 76, 58-70. https://doi.org/10.1016/j.ijhm.2018.04.004.

Chua, B-L., Lee, S., Goh, B. and Han, H. (2015). Impacts of cruise service quality and price on vacationers' cruise experience: Moderating role of price sensitivity. International Journal of Hospitality Management, 44, 131-145. http://dx.doi.org/10.1016/j.ijhm.2016.06.003.

Coulter, K.S. and Coulter, R.A. (2002). Determinants of trust in a service provider: The moderating role of length of relationship. Journal of Services Marketing, 16(1), 33-50.

Dolnicar, S., Cvelbar, L. K. and Grün, B. (2019). A Sharing-Based Approach to Enticing Tourists to Behave More Environmentally Friendly. Journal of Travel Research, 58(2) 241-252. https://doi.org/10.1177/o047287517746013.

Edvardsson, B., Kristensson, P., Magnusson, P. and Sundström, E. (2012). Customer integration within service development-A review of methods and an analysis of insitu and exsitu contributions. Technovation, 32, 419-429.

Ert, E., Fleischer, A. and Magen, N. (2016). Trust and reputation in the sharing economy: The role of personal photos in Airbnb. Tourism Management, 55, 62-73.

Ertz, M., Durif, F. and Arcand, M. (2019). A conceptual perspective on collaborative consumption. AMS Review, 9, 27-41. https://doi.org/10.1007/s13162-018-0121-3.

European Commission. (2014). A European Strategy for More Growth and Jobs in Coastal and Maritime Tourism. URL: https://ec.europa.eu/maritimeaffairs/publications/european-strategy-moregrowth-and-jobs-coastal-and-maritime-tourism_en. (Accessed on 01.05.2020)

Fang, B., Ye, Q. and Law, R. (2015). Effect of sharing economy on tourism industry employment. Research Notes and Reports / Annals of Tourism Research, 57, 234-278.

Fraanje, W. and Spaargaren, G. (2019). What future for collaborative consumption? A practice theoretical account. Journal of Cleaner Production, 208, 499-508.

Forbes. (2020). How will the coronavirus crisis affect future superyacht sales and charters? Burgess CEO Explains. URL: uperyacht-sales-and-charters-burgess-ceo-explains/\#5cdcdcd7980f_(Accessed on 01.06.2020)

Fuchs, G. and Reichel, A. (2006). Tourist Destination Risk Perception: The Case of Israel. Journal of Hospitality E Leisure Marketing, 14(2), 83-108, DOI: 10.1300/J150v14no2_o6. 
Frenken, K. and Schor, J. (2017). Putting the sharing economy into perspective. Environmental Innovation and Societal Transitions, 23, 3-10.

Fuchs, G. and Reichel, A. (2006). Tourist Destination Risk Perception: The Case of Israel. Journal of Hospitality \& Leisure Marketing, 14(2), 83-108, DOI: 10.1300/J150v14no2_o6.

Grönroos, C. (2006). Adopting a service logic for marketing. Marketing Theory,6 (3), 317-333.

Grönroos, C. (2008). Service logic revisited: who creates value? And who co-creates. European Business Review. 20(4), 298-314.

Gruen, T.W., Osmonbekov, T. and Czaplewski, A.J. (2007). Customer-to-customer exchange: Its MOA antecedents and its impact on value creation and loyalty. Journal of Academy of Marketing Science, 35, 537-549. DOI 10.1007/s11747-006-0012-2.

Guenzi, P. and Pelloni, O. (2004). The impact of interpersonal relationships on customer satisfaction and loyalty to the service provider. International Journal of Service Industry Management, 15(4), 365-384, https://doi.org/10.1108/09564230410552059.

Guttentag, D. (2015). Airbnb: disruptive innovation and the rise of an informal tourism accommodation sector. Current Issues in Tourism, 18(12), 1192-1217. http://dx.doi.org/10.1080/13683500.2013.827159.

Hall M.C. (2001). Trends in ocean and coastal tourism: the end of the last frontier? Journal of Ocean and Coastal Management, 44, 601- 618.

Hartl, B., Hoffman, E. and Kirchler, E. (2016). Do we need rules for 'what's mine is yours'? Governance in collaborative consumption communities. Journal of Business Research, 69, 2756-2763. http://dx.doi.org/10.1016/j.jbusres.2015.11.o11.

Hazee, S., Zwienenberg, T.J., Vaerenbergh, Y.V., Faseur, T., Vandenberghe, A. and Keutgens, O. (2020). Why customers and peer service providers do not participate in collaborative consumption. Journal of Service Management, 1757-5818. DOI 10.1108/JOSM-11-2018-0357.

Heitmann, S. (2011). Research Themes for tourism. Tourist Behavior and Tourism Motivation, Editors: Robinson, P. Heitmann, S. and Dieke, 31-44. DOI: 10.1079/9781845936846.oo31.

Hsieh, H-F. and Shannon, S.E. (2005). Three Approaches to Qualitative Content Analysis. Qualitative Health Research, 15(9), 1277-1288. DOI: 10.1177/1049732305276687.

Huber, A. (2017). Theorising the dynamics of collaborative consumptionpractices: A comparison of peer-to-peer accommodation andcohousing. Environmental Innovation and Societal Transitions, 23, 53-69.

Hyun, S.S. and Han, H. (2015). Luxury Cruise Travelers: Other Customer Perceptions. Journal of Travel Research, 54(1), 107-121.

Karlsson, L. and Dolnicar, S. (2016). Someone's been sleeping in my bed. Research Notes and Reports / Annals of Tourism Research, 58, 156-170. http://dx.doi.org/10.1016/j.annals.2016.02.005.

Karlsson, L., Kemperman, A. and Dolnicar, S. (2017). May I sleep in your bed? Getting permission to book. Annals of Tourism Research, 62, 1-12. http://dx.doi.org/10.1016/j.annals.2016.10.002.

Ko, Y.J. and Pastore, D.L. (2005). A Hierarchical Model of Service Quality for the Recreational Sport Industry. Sport Marketing Quarterly, 14, 84-97.

Konu, H. (2015). Developing nature-based tourism products with customers by utilising the Delphi method. Tourism Management Perspectives, 14, 42-54.

Krippendorf, K. (2013). Content Analysis: An Introduction to its Methodology. 3 rd ed. USA: Sage Publications, Inc.

Lacy, S. and Riffe, D. (1997). Sampling Error and Selecting Intercoder Reliability Samples for Nominal Content Categories. Journalism and Mass Communication Quarterly, 73(4).

Lamberton, C.P. and Rose, L. R. (2012). When Is Ours Better Than Mine? A Framework for Understanding and Altering Participation in Commercial Sharing Systems.Journal of Marketing, 76, 109-125. 
Latané, B. (1981). The psychology of social impact. American Psychologist, 36(4), 343356. https://doi.org/10.1037/0003-066X.36.4.343.

Leary, M.R. (2005). Sociometer theory and the pursuit of relational value: Getting to the root of selfesteem. European Review of Social Psychology, 16(1), 75-111. DOI: 10.1080/10463280540000007.

Leismann, K., Schmitt, M., Rohn, H. and Baedeker, C. (2013). Collaborative Consumption: Towards a Resource-Saving Consumption Culture. Resources 2013, 2, 184-203. DOI:10.339o/resources2030184.

Li, Y., Hu, C., Huang, C. and Duan, L. (2017). The concept of smart tourism in the context of tourism information Services. Tourism Management, 58, 293-300.

Lin, Z., Chen, Y. and Filieri, R. (2017). Resident-tourist value co-creation: The role of residents' perceived tourism impacts and life satisfaction. Tourism Management, 61, 436-442.

Lin, P. M.C., Fan, D.X.F., Zhang, H.Q. and Lau, C. (2019). Spend less and experience more: Understanding tourists' social contact in the Airbnb context. International Journal of Hospitality Management, 83, 65-73. https://doi.org/10.1016/j.ijhm.2019.04.007.

Lin, H. Zhang, M., Gursoy, D. and Fu, X. (2019). Impact of tourist-to-tourist interaction on tourism experience: The mediating role of cohesion and intimacy. Annals of Tourism Research, 76, 153-167.

Mahadevan, R. (2018). Examination of motivations and attitudes of peer to-peer users in the accommodation sharing economy. Journal of Hospitality Marketing and Management, 27(6), 679692. https://doi.org/10.108o/19368623.2018.1431994.

Martin, C.L. and Pranter, C.A. (1989). Compatibility Management: Customer-to-Customer Relationships in Service Environments, Journal of Services Marketing, 3(3), 5-15, https://doi.org/10.1108/EUMooooooooo2488.

Martin, C.L. (2016). Retrospective: compatibility management: customer-to-customer relationships in service environments, Journal of Services Marketing, 30(1), 11-15, https://doi.org/10.1108/JSM-102015-0319.

Miao, L., Mattila, A.S. and Mount, D. (2011). Other consumers in service encounters: A script theoretical perspective. International Journal of Hospitality Management, 30, 933-941.

Miller, M.L. and Auyong, J. (1991). Coastal Zone Tourism. A Potent Force Affecting Environment and Society. Marine Policy, 75-99.

Mitchell, V.W. and Greatorex, M. (1993). Risk Perception and Reduction in the Purchase of Consumer Services. The Service Industries Journal, 13(4), 179-200.

Mitchell, V.W. (1999). Consumer perceived risk: conceptualizations and models. European Journal of Marketing, 33(1/2), $163-195$.

Moon, H., Miao, L. Hanks, L. and Line, N.D. (2019). Peer-to-peer interactions: Perspectives of Airbnb guests and hosts. International Journal of Hospitality Management, $77.405-414$, https://doi.org/10.1016/j.ijhm.2018.o8.004.

Möhlmann, M. (2015). Collaborative consumption: determinants of satisfaction and the likelihood of using a sharing economy option again. Journal of Consumer Behaviour, 14, 193-207. DOI: $10.1002 / c b .1512$.

Murray, K.B. and Schlacter, J.L. (1990). The Impact of Services versus Goods on Consumers Assessment of Perceived Risk and Variability. Journal of Academy of Marketing Science, 18(1), 51-65.

Nguyen, J., Ferraro, C. and Sand, S. (2020). Similarity over difference: How congruency in customer characteristics drives service experiences. Journal of Business Research. https://doi.org/10.1016/j.jbusres.2019.09.015.

Nicholls, R. (2010). New directions for customer-to-customer interaction research. Journal of Services Marketing, 24(1), 87-97, https://doi.org/10.1108/o8876041011017916.

Nicholls, R. (2020). What goes on between customers? A cross-industry study of customer-to-customer interaction (CCI). Journal of Service Theory and Practice, 30(2), 123-147. DOI 10.1108/JSTP-05-20190112. 
Orams, M. (1996). Using Interpretation to Manage Nature-based Tourism. Journal of Sustainable Tourism, 4(2), 81-94.

Papathanassis, A. (2012). Guest-to-guest interaction on board cruise ships: Exploring social dynamics and the role of situational factors. Tourism Management, 33, 1148-1158.

Perren, R. and Grauerholz, L. (2015). Collaborative Consumption. International Encyclopedia of the Social and Behavioral Sciences, 2(4), 139-144. http://dx.doi.org/10.1016/B978-o-o8-097086-8.64143o.

Phua, V.C. (2018). Perceiving Airbnb as sharing economy: the issue of trust in using Airbnb. Current Issues in Tourism. 1-5. https://doi.org/10.1080/13683500.2018.1440539.

Pierce, P.L. and Lee, U.I. (2005). Developing the Travel Career Approach to Tourist Motivation Journal of Travel Research, 43, 226-237. DOI: 10.1177/0047287504272020.

Piscicelli, L., Cooper, T. and Fisher, T. (2015). The role of values in collaborative consumption: insights from a product-service system for lending and borrowing in the UK. Journal of Cleaner Production, 97, 21-29.

Pranter, C.A. and Martin, C.L. (1991). Compatibility Management: Roles in Service Performers. Journal of Services Marketing, 5(2), 43-53, https://doi.org/10.1108/o8876049110035530.

Price, L.L., Arnould, E.J. and Tierney, P. (1995). Going to Extremes: Managing Service Encounters and Assessing Provider Performance. Journal of Marketing, 59(2), 83-97.

Price, L.L. and Arnould, E.J. (1995). Commercial Friendships: Service Provider-Client Relationships in Context. Journal of Marketing, 63, 38-56.

Pwc (2015), The Sharing Economy, from URL: https://www.pwc.com/us/en/services/consulting/library/ consumer-intelligence-series/sharing-economy.html. (Accessed on 15/03/19).

Pyke, S., Hartwell, H., Blake, A. and Hemingway, A. (2016). Exploring well-being as a tourism product resource. Tourism Management, 94-105.

Ramaswamy, V. (2011). It's about human experiences...and beyond, to creation. Industrial Marketing Management, 40, 195-196.

Reichel, A., Fuchs, G. and Uriely, N. (2007). Perceived Risk and the Non-Institutionalized Tourist Role: The Case of Israeli Student Ex-Backpackers. Journal of Travel Research, 46, 217-226. DOI: 10.1177/0047287507299580.

Rihova, I., Buhalis, D., Moital, M. and Gouthro, M.B. (2015). Conceptualising Customer-to-customer Value Co-creation in Tourism. International Journal of Tourism Research, 17, 356-363.

Sevinç, F. and Güzel, T. (2017). Sustainable Yacht Tourism Practices. Management E Marketing Journal, $15,1,61-76$

Simkova, E. and Holzner, J. (2014). Motivation of Tourism Participants. Procedia - Social and Behavioral Sciences, 159, 660-664.

Sirdeshmukh, D., Singh, J. and Sabol, B. (2002). Consumer Trust, Value, and Loyalty in Relational Exchanges. Journal of Marketing, 66, 15-37.

Tajeddini, K. (2011). Customer Orientation, Learning Orientatıon, and New Service Development: An Empirical Investigation of The Swiss Hotel Industry. Journal of Hospitality \& Tourism Research, 35(4), 437-468.

Türkiye Cumhuriyeti Turizm ve Kültür Bakanlığı (TCKTB), 2018, Deniz Turizmi Araç Ve İșletmeleri İstatistikleri, (online) http://yigm.kulturturizm.gov.tr/Eklenti/59682,istatistiki-tablo-2018--agustospdf.pdf?o (Accessed on 15/10/18).

Turkish Chamber of Shipping (TCS) (2016), Maritime Sector Report. (online) URL: https://www.denizticaretodasi.org.tr/Media/SharedDocuments/sektorraporu/2016_sektor_en.pd $\mathrm{f}$ (Accessed on 15/10/18). 
Turkish Chamber of Shipping (TCS) (2019), Maritime Sector Report. (online) URL: https://www.denizticaretodasi.org.tr/Media/SharedDocuments/sektorraporu/2019_sector_en.pdf (Accessed on 11/06/20).

Thakor, M.V., Suri, R. and Saleh, K. (2008). Effects of service setting and other consumers' age on the service perceptions of young consumers. Journal of Retailing, 84(2), 137-149.

Tussyadiah, I.P. (2015). An Exploratory Study on Drivers and Deterrents of Collaborative Consumption in Travel. In Tussyadiah, I. and Inversini, A. (Eds.), Information \& Communication Technologies in Tourism Switzerland: Springer International Publishing.

Tussyadiah, I.P. and Pesonen, J. (2018). Drivers and barriers of peer-to-peer accommodation stay - an exploratory study with American and Finnish travellers. Current Issues in Tourism, 21(6), 703-720. http://dx.doi.org/10.108o/13683500.2016.114118o.

Vargo, S.L. and Lusch, R.F. (2004). Evolving to a New Dominant Logic for Marketing. Journal of Marketing, 68, 1-17.

Wei, W., Lu, Y (T), Miao, L., Cai, L.A. and Wang, C. (2017). Customer-customer interactions (CCIs) at conferences: An identity Approach. Tourism Management, 59, 154-170.

$\mathrm{Wu}, \mathrm{C}$. H-J. (2007). The impact of customer-to-customer interaction and customer homogeneity on customer satisfaction in tourism service-The service encounter prospective. Tourism Management, 28, 1518-1528.

$\mathrm{Wu}$, C.H-J. and Liang, R.D. (2009). Effect of experiential value on customer satisfaction with service encounters in luxury-hotel restaurants. International Journal of Hospitality Management, 28, 586593 .

Yang, S., Song, Y., Chen, S. and Xia, X. (2017). Why are customers loyal in sharing-economy services? A relational benefits perspective. Journal of Services Marketing, 31(1), 48 - 62. DOI 10.1108/JSM-012016-0042.

Yoo, J., Arnold, T.J. and Frankwick, G.L. (2012). Effects of positive customer-to-customer service interaction. Journal of Business Research, 65, 1313-1320.

Received: 08/06/2020

Accepted: 26/o9/2020

Coordinating editor: Martina Gonzalez-Gallarza 